\title{
Survey on Prevalence of Newcastle Disease Antibodies in Village Poultry at Live Birds Markets in Gombe, Nigeria
}

\author{
Lawal JR ${ }^{1 *}$, El-Yuguda AD ${ }^{2}$ and Ibrahim UI ${ }^{1}$ \\ ${ }^{1}$ Department of Veterinary Medicine, University of Maiduguri, Nigeria \\ ${ }^{2}$ Animal Virus Research Laboratory, Department of Veterinary Microbiology and Parasitology, University of Maiduguri, Nigeria
}

${ }^{*}$ Corresponding author: Dr. Jallailudeen Rabana Lawal, Department of Veterinary Medicine, University of Maiduguri, P.M.B 1069, Maiduguri, Borno State, Nigeria, Tel: +234 8032886428; E-mail: rabanajallailudeen@yahoo.com

Received Date: Nov 08, 2016; Accepted Date: Dec 12, 2016; Published Date: Dec 19, 2016

Copyright: (c) 2016 Lawal J R et al. This is an open-access article distributed under the terms of the Creative Commons Attribution License, which permits unrestricted use, distribution, and reproduction in any medium, provided the original author and source are credited.

Citation: Lawal J R, El-Yuguda A D, Ibrahim U I. Survey on Prevalence of Newcastle Disease Antibodies in Village Poultry at Live Birds Markets in Gombe, Nigeria. J Anim Sci Livest Prod. 2016, 1:1.

\section{Abstract}

The study aimed to determine the seroprevalence of Newcastle disease (ND) amongst some village poultry species at poultry markets in Gombe, Nigeria. A total of 1200 (841 Village chickens, 320 Guinea Fowls and 39 Pigeons) sera samples were tested. Haemagglutination inhibition test revealed an overall ND virus (NDV) antibodies prevalent rate of $53.7 \%$ (644/1200). The seroprevalence of antibodies to ND was found to be higher in Village chickens $527 / 841$ (62.7\%) followed by Pigeons 19/39 (48.7\%) and Guinea Fowls 98/320 (30.6\%) respectively and were found to be seropositive with Geometric Mean Titres (GMT) of 1.9 to 5.9. There was no significant difference $(p>0.05)$ in antibodies to ND seroprevalence rates among the different sampling locations. Species of poultry was found to be associated with ND seroprevalence $(P \leq 0.05)$ in this study. Newcastle disease antibodies was statistically significantly $(P<0.0001)$ higher in Village chickens compared to Guinea Fowls at $95 \mathrm{Cl}$ (odd ratio $=0.4887$ ). However, there was no statistical significance $(P=0.4106)$ difference of ND antibodies between Village chickens and Pigeons at $95 \% \mathrm{Cl}$ (odd ratio $=0.7775$ ) and also between pigeons and Guinea Fowls ( $\mathrm{P}=0.1426$ at $95 \% \mathrm{Cl}$, odd ratio $=1.591)$. These poultry species could play significant role in the epidemiology and transmission of the Newcastle disease to more the susceptible commercial exotic chickens or other immune deficient village poultry species especially where reared in close proximity. Therefore, free routine ND vaccination campaign should be launched in the study areas with more emphases targeting the Village poultry species in order to block the epidemic cycle of the virus. Moreover, village poultry farmers should be enlightened on the economic significance of the disease and the need to maintain strict biosecurity measures on their poultry farms.

Keywords: Newcastle disease antibody; Seroprevalence; Village poultry; Hemagglutination inhibition test; Gombe; Nigeria.

\section{Introduction}

In developing countries, poultry production is being subjected to great pressure to meet the demand for animal protein required by the increasing human population, and also to have surplus for international trade [. Village poultry production, consist of edible domestic birds including chickens, ducks, guinea fowls, geese, pigeons, turkeys and quails among others which are mostly raised under the free range extensive husbandry systems especially in the sub-urban and rural areas [2-4]. In Africa, village poultry production system has influenced human civilization in several aspects which include economic, nutritional and socio-cultural aspects of livelihoods of poor rural households [5]. Village poultry products have ensured household food security as it supplies high quality animal protein (meat and egg) where used as food, petty cash derived from sales of poultry products, poverty alleviation and create jobs for rural dwellers [6,7]. Village poultry are also shared as gift among relatives and friends; they are also used as sacrifices during religion and cultural festivals [6-8]. Compared to a number of other livestock species, fewer social and religious taboos are related to the production, marketing and consumption of poultry products in developing countries of Africa including Nigeria [9]. In Nigeria, village poultry represents about $84 \%$ (115.8 million) of the 137.6 million poultry population while the commercial exotic poultry is $16 \%(21.7$ million), thus, the village poultry industry is considered an important form of poultry production system [10-13].

Unfortunately, village poultry production is faced by a number of constraints which include predators, poor housing, management, inadequate feeding and most importantly, the menace of infectious diseases which have been identified as one of the major constraints to successful village poultry production in Nigeria [14-17]. High losses of village poultry due to diseases pose a serious threat to food security and livelihood of many rural families $[15,18]$. The most devastating disease of rural poultry is Newcastle disease (ND) [19-23]. Newcastle disease (ND) is an acute, highly infectious and highly pathogenic viral disease of domestic poultry and other species of birds regardless of variation in sex and age [24-29]. Newcastle disease virus 
(NDV) have previously been reported to exists in 10 serotypes of Avian Paramyxovirus (APMV); APMV-1 to APMV-10 [30,31]. However, more recently, two distinct serotypes APMV-11 and APMV-12 of NDV have been isolated which makes it twelve (12) defined NDV serotypes [32-36], there are additional APMV-13 and APVM-14 that are putative, isolated Newcastle disease virus but not yet recognized [36,37]. Newcastle disease virus that causes clinical disease in birds belongs to virulent serotype 1 (APMV-1) [38-40]. Newcastle disease virus (NDV) has a wide host range, including approximately 241 species of 27 orders, out of known 50 orders of birds [41]. More commonly affected species include chickens, turkeys, ducks, pigeons, [24,26,42,43] guinea fowl, Japanese quail and many wild birds of all ages [44-47]. The most susceptible avian species to this disease are chickens (Gallus domesticus) $[43,48]$. The disease is considered a major constraint to poultry production in developing countries of Africa including Nigeria, in both commercial and village poultry rearing systems $[49,50]$.

The epizootiology and threat posed by ND to the poultry industry have earlier being attached mainly to the commercial exotic poultry which are reared under the intensive management system. Attention, however, were turned to the scavenging village poultry species when various strains and pathotypes of NDV were isolated from apparently healthy village chickens, ducks, guinea fowls, pigeons and other nondomesticated avian species [51-58].

Newcastle disease is usually transmitted from farm to farm mainly through introduction of live infected birds, selling and giving away sick birds, through inhalation of virus from contaminated air, ingestion of virus in contaminated feed and water [59]. Outbreaks of the disease may be associated with mortality of up to $100 \%$ [55,60-63]. Newcastle disease is economically significant since it causes high morbidity and mortality, reduces egg production, deteriorates egg quality and impairs live performance $[64,65]$. It has been argued that Newcastle disease may represent a bigger drain on the world economy than any other animal viral disease since it also affects international trade $[19,26,31,40,66]$ Due to the severe nature of ND and the related consequences, NDV is included in "LISTED" agents (reportable disease) by Office International des Epizooties (OIE) $[67,68]$. Notification is required by OIE of any outbreak of ND [69], when it meets certain criteria of virulence $[40,43]$. The first documented outbreak of ND in Nigeria occurred between December, 1952 and February 1953 in and around Ibadan [22]. The disease has since this time remained a notable problem in poultry production systems in the country [70] and has become endemic with annual epidemics recorded in highly susceptible flocks with pockets of outbreaks occurring in between the annual epidemic periods $[22,63]$. Outbreaks of Newcastle disease in Nigeria were reported to be more likely in farms that rear exotic birds mixed with village poultry species [11,71-73]. Although, the village poultry are apparently more resistance to the disease but the fact that they serves as NDV carriers and reservoirs they tend to exert a high viral pressure on the exotic commercial flocks thus revealing the slightest failure in vaccination [74]. The disease was also reported to be more common during the cold dry harmattan period (NovemberMarch) $[61,73,75,76)$. Newcastle disease has been reported endemic in many developing countries of Africa such as Kenya [77,78]; Cameroon [74,79]; Tanzania [80]; Ethiopia [81,82] and Egypt [83]. In Nigeria, several prevalence studies on Newcastle disease virus antibodies in village poultry have been conducted $[21,22,50,53,56,58,84-88]$. Moreover, the prevalence of Newcastle disease have been categorically reported in most parts of the Northern Nigeria such as Sokoto State [59]; Zamfara State [89]; Yobe State [90]; Bauchi State [57]; Borno State [21]; Jigawa State [91]; Kwara State [76]; Kogi State [47]; Nassarawa State [92,93]; Kaduna State [94], Plateau State [56] and Abuja FCT $[84,88]$. Establishment of Newcastle disease status in Gombe is therefore of great importance. This present study therefore aimed at detecting antibodies to Newcastle disease virus infection from some village poultry species present for slaughter in major live birds markets that serves as main collection center of sales of village poultry species brought into Gombe metropolis from different parts of Gombe State and other neighboring States.

\section{Materials and Methods}

\section{Study area}

This study was carried out in Gombe, the capital city of Gombe State, and Northeastern Nigeria. Gombe township lies between Latitude $10^{\circ} 08^{\prime} \mathrm{N}$ and $11^{\circ} 24^{\prime} \mathrm{E}$ and longitude $11^{\circ} 02^{\prime}$ $\mathrm{N}$ and $11^{\circ} 18^{\prime} \mathrm{E}$ of the Greenwich Meridian. The size of the town is $20,265 \mathrm{~km} 2$, with an estimated population of 261,536 inhabitants. Gombe town is between $400-450$ feet, above sea level. The climatic and edaphic factors favor crop and livestock agriculture. The occupation of most of the inhabitants is agriculture which includes food and cash crop production; village poultry, cattle, sheep and goat rearing under the extensive and semi-intensive animal husbandry management systems. The annual rainfall ranges between $850-1000 \mathrm{~mm}$, with two distinct seasons. The rainy season which starts from May to October and dry season, from November-April. Average daily temperatures are $34^{\circ} \mathrm{C}$ in April and $27^{\circ} \mathrm{C}$ in August. The relative humidity ranges from $70-80 \%$ in August and decreases to about $15-20 \%$ in December. The natural vegetation is typically that of the Sudano-Sahelian Savannah, which is composed of shrubs, herbs, grasses and sparsely distributed trees. Cereals such as ground nut, maize, guinea corn, millet and cowpea are predominantly grown in the area and provide enough fodder for the animals $[95,96]$.

\section{Sample collection}

Six (6) major live bird markets/dressing slabs within Gombe metropolis were used for this study. The dressing slabs included: Gombe main market, Pantami market, Dukku park market, Riyald \Bagadaza market, Shongo park market and Tudun wada market. These poultry markets are located at strategic places within the study area and they serve as collection centers for all the live poultry species brought for sale and or dressing from households within Gombe Township, other villages and other poultry markets in Gombe State and other neighboring States. Three to five milliliters $(3-5 \mathrm{ml})$ of blood was collected into plain vacutainer tubes from the severed jugular vein of any poultry 
species (Village chickens, guinea fowls and pigeons) with no previous history of conventional ND vaccination. These tubes were labeled appropriately and kept in a slanting position at room temperature to allow blood samples to clot. The clotted blood samples were centrifuged at 1,500 rpm and the serum samples were harvested using disposable Pasteur pipettes. The separated serum samples were transferred into labeled cryotubes and stored at $-20^{\circ} \mathrm{C}$ until tested.

\section{Sample Size Determination}

The number of poultry required for this study was determined using the formula given by Thrusfield [97] for simple random sampling. The size of sample was determining using $95 \%$ level of confidence, $50 \%$ expected prevalence since there was no previous work in this study area and $0.05 \%$ desired absolute precision. Therefore, a total of 841 village chickens, 320 guinea fowls and 39 pigeons which give overall total of 1200 sera that were sampled.

\section{Source of Newcastle disease vaccine}

The Newcastle disease vaccine (LaSota) that was used for the Haemagglutination Inhibition ( $\mathrm{HI}$ ) test was obtained from the Viral Research Department, National Veterinary Research Institute (NVRI), Vom, Plateau State, Nigeria. The Haemagglutination (HA) and Haemagglutination Inhibition ( $\mathrm{HI}$ ) test was carried out according to the FAO protocol [98].

\section{Serology}

Serum samples were tested for Newcastle disease virus specific antibodies using a modification of the
Haemagglutination Inhibition ( $\mathrm{HI}$ ) test as previously described by Baba et al. [99]. ND-HI titer of $\log 23$ and above is generally accepted as positive for specific immunity [100].

\section{Data analysis}

Haemagglutination inhibition titres obtained were expressed as geometric mean titre (GMT) values according to the method described by Garner et al., using the formula $X_{\text {geo }}=\operatorname{antilog}_{10}\{1 / n$ $\left.\left(\sum \mathrm{f}_{\mathrm{i}} \log _{10} \mathrm{X}_{\mathrm{i}}\right)\right\}$ where $\mathrm{n}=$ number tested, $\mathrm{X}_{\mathrm{i}}=$ the reciprocal of dilution and $f_{i}=$ frequency. The data obtained from the study were stored and coded accordingly using Microsoft Excel-2007. And data collected were analyzed by the Statistical Package for Social Sciences (SPSS) version 17.0. Chi-square test was conducted to find out the association between the occurrence of ND antibodies and the species of village poultry. The prevalence was expressed in percentage. Significance was determined when $p<0.05$. Calculation of the lower and upper limits of the $95 \%$ confidence interval for a proportion was done according to the methods described by Newcombe [101].

\section{Results}

An overall prevalence rate of $644 / 1200$ (53.7\%) was observed among the different species of village poultry examined. Out of 841 village chickens sera samples tested 527 (62.7\%) were seropositive for ND antibodies, while out of 320 guinea fowls and 39 pigeons sera tested, 98 (30.6\%) and 19 (48.7\%) were seropositive for ND antibodies respectively. The ND seroprevalence in the different poultry species sera surveyed was expressed in Geometric Mean Titre (GMT) values and these ranges from 1.9 to 5.9 (Table 1 ).

Table 1 Prevalence and Distribution of Newcastle disease $\mathrm{HI}$ antibody titres in different types of poultry species in Gombe, Nigeria ( $\mathrm{HI}$ antibody titre of $\geq 4 \log 2$ was considered protective).

\begin{tabular}{|c|c|c|c|c|c|c|c|c|c|c|}
\hline \multirow{2}{*}{ Type of poultry sampled } & \multirow{2}{*}{$\begin{array}{l}\text { No. of sera } \\
\text { tested }\end{array}$} & \multirow{2}{*}{ No. $(\%)$ positive sera } & \multicolumn{8}{|c|}{ Distribution of $\mathrm{HI}$ antibody titres } \\
\hline & & & 2 & 4 & 8 & 16 & 32 & 64 & 128 & 256 \\
\hline Village chickens & 841 & $527(62.7)$ & 50 & 94 & 68 & 52 & 115 & 116 & 32 & 0 \\
\hline Guinea Fowls & 320 & $98(30.6)$ & 17 & 37 & 11 & 10 & 13 & 8 & 2 & 0 \\
\hline Pigeon & 39 & $19(48.7)$ & 4 & 4 & 5 & 4 & 2 & 0 & 0 & 0 \\
\hline Total & 1200 & $644(53.7)$ & 71 & 137 & 84 & 66 & 130 & 124 & 43 & 0 \\
\hline
\end{tabular}

The results of seroprevalence of Newcastle disease antibodies in village chickens, guinea fowls and pigeons from different poultry markets/dressing slabs in Gombe revealed that no poultry markets/dressing slabs was found to be free of ND antibodies. There was no statistical significance $(P>0.05)$ noted in the distribution of the ND $\mathrm{HI}$ antibodies in all the poultry markets sampled, but the seroprevalence among the different poultry species varied significantly $(P<0.05)$. The highest prevalence rate among village chickens sera tested occurred in
Gombe main market (72.2\%) and Pantami market (70.9\%), while the lowest prevalence rate occurred in Dukku park market (47.8\%). However, the highest prevalence rate among guinea fowls sera tested occurred in Pantami market (45.8\%), while the lowest prevalence rate occurred in Dukku park market (20.3\%). Moreover, the highest prevalence rate among pigeons sera tested occurred in Gombe main market (71.4\%), while the lowest prevalence rate occurred in Tudun wade market $(21.4 \%)$ (Table 2).

Table 2 Seroprevalence of Newcastle disease antibodies in village chickens, guinea fowls and Pigeons from different poultry markets/ dressing slabs in Gombe, Nigeria. 


\begin{tabular}{|c|c|c|c|c|c|c|}
\hline \multirow{2}{*}{ Parameters } & \multicolumn{6}{|c|}{ Site of serum sample collection } \\
\hline & $\begin{array}{c}\text { Gombe main } \\
\text { market }\end{array}$ & Pantami market & Riyald market & $\begin{array}{l}\text { Dukku park } \\
\text { market }\end{array}$ & $\begin{array}{l}\text { Tudun wada } \\
\text { market }\end{array}$ & $\begin{array}{l}\text { Shongo park } \\
\text { market }\end{array}$ \\
\hline $\mathbf{N}$ & 158 & 141 & 121 & 136 & 157 & 128 \\
\hline $\mathbf{n}$ & 114 & 100 & 81 & 65 & 78 & 89 \\
\hline $\begin{array}{c}\text { Seroprevalence in Village } \\
\text { chickens }(\%)\end{array}$ & 72.2 & 70.9 & 66.9 & 47.8 & 49.7 & 69.5 \\
\hline $95 \% \mathrm{Cl}$ & $0.647-0.7885$ & $0.6295-0.7778$ & $0.5815-0.7469$ & $0.3957-0.5613$ & $0.4196-0.541$ & $0.6108-0.7684$ \\
\hline $\mathbf{N}$ & 35 & 59 & 74 & 64 & 29 & 59 \\
\hline $\mathbf{n}$ & 7 & 27 & 27 & 13 & 7 & 17 \\
\hline $\begin{array}{c}\text { Seroprevalence in Guinea } \\
\text { Fowls (\%) }\end{array}$ & 20 & 45.8 & 36.5 & 20.3 & 24.1 & 28.8 \\
\hline $95 \% \mathrm{Cl}$ & $0.1004-0.3589$ & $0.337-0.5834$ & $0.2644-0.4787$ & $0.1227-0.3171$ & $0.1222-0.4211$ & $0.1883-0.4138$ \\
\hline $\mathbf{N}$ & 7 & 0 & 5 & 0 & 14 & 13 \\
\hline $\mathbf{n}$ & 5 & 0 & 2 & 0 & 3 & 9 \\
\hline Seroprevalence in pigeons (\%) & 71.4 & 0 & 40 & 0 & 21.4 & 69.2 \\
\hline $95 \% \mathrm{Cl}$ & $0.3589-0.9178$ & 0 & $0.1176-0.7693$ & 0 & $0.0757-0.4759$ & $0.4237-0.8732$ \\
\hline $\mathbf{N}$ & 200 & 200 & 200 & 200 & 200 & 200 \\
\hline $\mathbf{n}$ & 126 & 127 & 110 & 78 & 88 & 115 \\
\hline Overall Seroprevalence (\%) & 63 & 63.7 & 55 & 39 & 44 & 57.5 \\
\hline $95 \% \mathrm{Cl}$ & $0.5612-0.6939$ & $0.5663-0.6986$ & $0.4808-0.6174$ & $0.3251-0.4591$ & $0.373-0.5093$ & $0.5057-0.6415$ \\
\hline
\end{tabular}

Key: $\mathrm{N}$, number of sera sampled; $\mathrm{n}$, number of $\mathrm{HI} / \mathrm{HA}$ positive sera; $95 \%$ Confidence interval; $\mathrm{P} \leq 0.05$ was considered as significant.

The result of comparative analysis of seroprevalence of Newcastle disease antibodies among the different village poultry species in Gombe shows that ND seroprevalence was statistically significantly $(\mathrm{P}<0.0001)$ higher in Village chickens compared to guinea fowls at $95 \% \mathrm{Cl}$ (odd ratio=0.4887). However, there was no statistical significance ( $P=0.4106)$ difference of ND antibodies between village chickens and pigeons at $95 \% \mathrm{Cl}$ (odd ratio $=0.7775)$ and also between pigeons and guinea fowls $(\mathrm{P}=0.1426$ at $95 \% \mathrm{Cl}$, odd ratio=1.591) (Table 3).

Table 3 Comparative analysis of Seroprevalence of Newcastle disease antibodies among village Poultry species in Gombe, Nigeria

\begin{tabular}{|c|c|c|c|c|c|c|c|}
\hline \multirow{2}{*}{ Poultry Species } & \multirow{2}{*}{ Number of sera tested $(\mathrm{N})$} & \multirow{2}{*}{ HI/HA positive (n) } & \multirow{2}{*}{ Prevalence (\%) } & \multicolumn{2}{|l|}{$95 \mathrm{Cl}$} & \multirow[t]{2}{*}{ P-value } & \multirow{2}{*}{ OR } \\
\hline & & & & Lower limit & Upper limit & & \\
\hline Village chickens & 841 & 527 & 63 & & & & \\
\hline Guinea Fowls & 320 & 98 & 31 & 0.38 & 0.6 & $P<0.0001$ & 0.5 \\
\hline Village chickens & 841 & 527 & 63 & & & & \\
\hline Pigeons & 39 & 19 & 49 & 0.44 & 1.4 & $P=0.4106$ & 0.8 \\
\hline Guinea Fowls & 320 & 98 & 31 & & & & \\
\hline Pigeons & 39 & 19 & 49 & 0.88 & 2.9 & $P=0.1426$ & 1.6 \\
\hline
\end{tabular}

Key: N, number of sera sampled; $n$, number of $\mathrm{HI} / \mathrm{HA}$ positive sera; $95 \%$ Confidence interval; $\mathrm{P} \leq 0.05$ was considered as significant.

\section{Discussion}

Newcastle disease (ND) is considered an endemic disease among backyard and commercial poultry industry in Nigeria. Despite vigorous vaccination trials and campaigns there were still reports of frequent outbreaks of the disease in the country among village and commercial poultry population [74,102]. However, seroprevalence survey still remains an important step towards immediate detection and effective control of Newcastle disease (ND) among poultry species in Nigeria where the disease is endemic. Haemagglutination Inhibition (HI) antibody titer between $0 \log ^{2}$ and $3 \log ^{2}$ is considered negative because they 
produce no antibody against the virus while $\mathrm{HI}$ antibody titer between $4 \log ^{2}$ and $8 \log ^{2}$ is considered positive for antibodies production against the virus based on OIE recommendation of $2000[103,104]$. The overall seroprevalence of Newcastle disease virus (NDV) antibodies in village poultry in this study was $53.7 \%$, this findings tally with $55.5 \%$ previously reported by Lawal et al. [105] in a ten years retrospective study of ND cases reported and diagnosed in Veterinary clinics in Gombe metropolis. The occurrence of antibodies to ND in the tested sera of apparently healthy village poultry species with no previous history of conventional ND vaccination as observed in this study is an indication of natural infection by non-virulent strain of NDV which may not cause clinical disease but act like vaccine. However, infection may be due to non-virulent strain of ND which might have stimulated immune response of the seropositive birds. The prevalence rate is higher in village chickens $(62.7 \%)$ compared to pigeon $(48.7 \%)$ and guinea fowls $(30.6 \%)$. This suggested that the village chickens are more susceptible to the Newcastle disease virus than other village poultry species in the study area and should be considered as an important factor in the epidemiology of the disease. The economic importance of ND to the village poultry farmers is not only due to the high mortality rate in infected birds but that such affected birds if survived could eventually become carriers and enhance the dissemination of the virus to other healthy susceptible flocks. Of interest in this study is the detection of NDV antibodies from the village poultry sampled in all the live birds markets in Gombe metropolis. This observation shows that ND naturally infected birds are brought to these markets from various localities for sale and are either bought for human consumption or replacement in poultry flocks. This could enhance the continuous circulation and transmission of NDV amongst susceptible birds in the study area. However, It is noteworthy that these village poultry species have no history of previous vaccinated against Newcastle disease, therefore, detection of ND antibodies is an indication of natural infection and since the poultry species sampled are adults birds the presence of maternal antibodies can be ruled out, because maternal antibodies disappear after the age of 3-4 weeks [21].

The seroprevalence of $53.7 \%$ NDV antibodies recorded in village chickens in this study was closer to those reported from some States which shares bounders with Gombe State, 56.3\% was reported in Bauchi State [57] and 51.0\% in Borno State [21]. However, it is lower than $74.3 \%$ previously reported in Maiduguri $[19,20]$ but higher than $34.5 \%$ reported by Sule et al. [90] in Yobe State. In Adamawa State, Bobbo et al. [106] have reported the susceptibility of three phenotypes (Frizzle, Naked neck and Smooth feathered types) of Village chickens to ND which revealed that no ecotype of village in Northeastern Nigeria is definitely resistance to velogenic strain of the disease. Other studies conducted on village chickens at live bird markets in Nigeria by Ameji et al. [107], Chollom et al. [108], Jibril et al. [89] and Eze and Ike, showed 96\%, 35.8\%, 25.5\% and $65.1 \%$ seroprevalence rates respectively. These observed regional differences in ND seroprevalence showed ecological area variation in NDV activity and may perhaps be a reflection of the impact of environment on the viability and spread of NDV and its epidemiology [50]. It has also been reported that most village chickens flocks in Nigeria are seldom routinely vaccinated against ND using the conventional vaccines [109]. Therefore, detection of antibodies to ND in apparently healthy chickens is indicative of natural infection by non-virulent or lentogenic strains of the virus that may not cause clinical diseases but acts like vaccine. However, the bird may be at the period of sampling be incubating the disease in a subclinical state $[18,50,59,74]$.

The ND seroprevalent rate of $30.6 \%$ reported in guinea fowls from this study is relatively lower than $39.8 \%$ reported in Borno and Yobe State by Hassan et al. $15.0 \%$ and $13.4 \%$ reported in Jos, Plateau State by Ibu et al. [110] and Mai et al. respectively. The difference may be as a result of the sample size, the period of sample collections and diagnostic methods employed. Although fatal outbreaks of ND has been reported among guinea fowls in Nigeria despite the fact that these species of birds seem to be more resistant to ND than chickens [93,111-113] have reported that Newcastle disease virus is enzootic among guinea fowls in Borno and Yobe States, Northeastern Nigeria.

However, Boakye et al. [114] recently reported $48.6 \%$ ND seroprevalence in guinea fowls in Ghana. In rural households of Northern Nigeria, it is customary to see village chickens and guinea fowls mingling and roaming around scavenging for food together, these events can create the chances of close contact for direct transmission of ND among the two species of birds.

The seroprevalence of $48.7 \%$ of NDV antibodies recorded in pigeons is higher than $44 \%$ reported by Sai'du et al. in domestic pigeons in Zaria, Kaduna State. Domestic pigeons and doves were reported to be more susceptible to ND virus than other members of the columbiformes [115]. Although, there were no reports of clinical outbreaks of ND in domesticated pigeons in Nigeria, there has only been serological evidence of ND infection in pigeons in Nigeria [116]. Pigeons are nevertheless infected with ND virus and may therefore serve as reservoirs of ND virus for the more susceptible poultry species $[115,117]$. Outbreak of ND had been reported from UK due to contamination of poultry feed with faeces of pigeon [118]. This report signifies that ND infected pigeons can play a significant role in transboundry transmission of the disease since they can fly several miles across regions. As far as our knowledge, this is the first time a higher prevalence rate of $48.7 \%$ is recorded in pigeons in Northeastern Nigeria. Although, $\mathrm{HI}$ antibody titre of $\geq 4 \log 0032$ was considered protective against NDV infection [21,119], some of the sera had reciprocal titres close to $4 \log 2$. Birds partially immuned can succumb to a velogenic NDV infection or maintain a subclinical disease during which active excretion of the virus may occur making them a possible source of infection for incontact birds $[58,120,121]$.

\section{Conclusion}

The finding of this study revealed the presence of antibodies to ND in sera of apparently healthy village poultry species in Gombe, Nigeria. Newcastle disease antibodies were more frequent in the tested sera of Village chickens compared to sera of Pigeons and Guinea Fowls. Village chickens may have been more exposed to the virus than the other poultry species or probably their antibody levels have decreased below the 
threshold. Village poultry species could play a significant role in the epidemiology and transmission of the infection to the more susceptible commercial exotic chickens or immune deficient village poultry species especially where reared together or in close proximity. The disease may therefore be considered a threat to successful village poultry production system in the study area. Therefore, it is recommended that routine ND vaccination campaign should be launched in the study area. To effectively block the epidemic cycle of the virus and control this disease, more attention should be given to village poultry species. Village poultry farmers should be enlightened on the economic significance of the disease and the need to maintain strict biosecurity measures on their poultry farms. Also, researches on isolation and characterization of the spreading virus strains should be carried out in order to provide more information that could be used in formulating and planning for effective control of Newcastle disease in Gombe State.

\section{Acknowledgements}

The authors wish to thank the Technologists of the Animal Virus Research Laboratory, Department of Veterinary Microbiology and Parasitology, University of Maiduguri and those of the Department of Veterinary Medicine Research Laboratory, University of Maiduguri for their technical assistance.

\section{References}

1. Tamiru F, Dagmawit A, Askale G, Solomon S, Morka D et al. (2014) Prevalence of Ectoparasite Infestation in Chicken in and Around Ambo Town, Ethiopia. Journal of Veterinary Science and Technology 5: 4 .

2. Njue SW, Kasiiti, JL, Macharia JM, Garcheru SG, Mbugua HC (2002) Health management improvements of family poultry production in Africa: survey results from Kenya. In: Characteristics and parameters of family poultry production in Africa. Publication of FOA / IAEA Co-ordinated Research Programme Pp. 39-45.

3. Wethli ED (2003) The importance of rural village chicken production. Poultry Bulletin 330.

4. Copland JW, Alders RG (2005) The Australian village poultry development Programme in Asia and Africa. World's Poultry Science Journal 61: 31-37.

5. Alemu N, Muktar Y, Kassaye D, Hiko A (2015) Prevalence of Lice and Fleas in Backyard Chickens of Bishoftu Town, Ethiopia. American-Eurasian J Agric \& Environ Sci 15: 2136-2142.

6. ILRI (2014) Livestock policy analysis. ILRI Training Manual ILRI, Nairobi, Kenya.

7. Mulugeta A, Chanie M, Bogale B, (2013) Major Constraints of Village Poultry Production in Demba Gofa District of Southern Region, Ethiopia. British J Poultry Sci 2: 1-6.

8. Alders RG, Spradbrow PB, Young MP (2009) Village chickens, poverty alleviation and the sustainable control of Newcastle disease. ACIAR Proceedings No. 131, Pp. 235.

9. Radfar MH, Khedri J, Adinehbeigi K, Nabavi R, Rahmani K (2012) Prevalence of parasites and associated risk factors in domestic pigeons (Columba livia domestica) and free-range backyard chickens of Sistan region, east of Iran. J Parasit Dis 36: 220-225.
10. Federal Ministry of Agriculture and Rural Development (FARD) (2006). Highly Pathogenic Avian Influenza Standard Operating Procedures.

11. Adene DF, Oguntade AE (2006) The Structure and Importance of the Commercial and Village Based Poultry Industry in Nigeria. Food and Agricultural organization (FAO) Poultry Production Systems; ECTAD/AGAP, Pp. 1-102.

12. Duru S, Saidu L, Akpa GN, Jokthan GE, Kabir M, et al. (2008) Prevalent disease in Local Poultry: A case study of Zaria area, Kaduna state. In: Proceedings of the 13th Annual Conference of the Animal Science Association of Nigeria (ASAN), Pp. 683-686.

13. Ekpo UF, Ogbooye AA, Oluwole AS, Takeet M (2010) A Preliminary Survey on the Parasites of Free Range Chicken in Abeokuta, Ogun State, Nigeria. J Nat Sci Engr Tech 9: 123-130.

14. El-Yuguda AD, Ngulde IS, Abubakar MB, Baba SS (2007) Village chicken health, management and production indices in selected villages of Borno state, Nigeria. Family Poultry 17 2: 41-48.

15. Musa U, Abdu PA, Dafwang II, Edache JA, Ahmed MS, et al. (2008) A survey of causes of mortality in some Local chicken flocks in Plateau state: In: Proceedings of the 33rd Annual Conference of the Nigeria Society of Animal Production (NSAP), Pp. 551-554.

16. Amede $Y$, Tilahun K, Bekele M (2011) Prevalence of Ectoparasites in Haramaya University Intensive Poultry Farm. Global Veterinaria, 7: 264-269.

17. Ayodele PO, Okonko IO, Okerentugba PO, Nwanze JC, Onoh CC (2013) Effect of Anthocleista nobilis root extract on the haematological indices of poultry chicken challenged with Newcastle disease virus (NDV). Nature and Science, 11: 82-91.

18. Chukwudi OE, Chukwuemeka ED, Mary U (2012) Newcastle disease virus shedding among healthy commercial chickens and its epidemiological importance. Pak Vet J 32: 354-356.

19. Nwanta JA, Abdu PA, Ezema WS (2008a) Epidemiology, Challenges and Prospects for control of Newcastle disease in village poultry in Nigeria. World's Poultry Science Journal 64: 119-127.

20. Nwanta JA, Egege SC, Alli-Balogun JK, Ezema WS (2008b) Evaluation of prevalence and seasonality of Newcastle disease in chicken in Kaduna, Nigeria. World's Poultry Science Journal 64: 416-423.

21. El-Yuguda AD, Baba SS, Ibrahim UI, Brisibe F (2009) Newcastle disease and Infectious Bursal disease among village chickens in Borno State, Nigeria. Family Poultry, 18 (1 and 2): 16-23.

22. Okwor EC, Eze DC (2010) The Annual Prevalence of Newcastle Disease in Commercial Chickens Reared in South Eastern Savannah Zone of Nigeria. Res J Poult Sci 3: 23-26.

23. Diel DJ, Susta L, Garcia SC, Killian ML, Brown CC, et al. (2012) Complete genome and clinicopathological characterization of a virulent newcastle disease virus isolate from South America. Journal of Clinical Microbiology 50: 378-387.

24. Seal BS, King DJ, Sellers HS (2000) The avian response to Newcastle disease virus. Developmental and Comparative immunology 24: 257-268.

25. Al-Garib, S. O., Gielkens, A. L. J., and Koch, G. (2003). Review of Newcastle disease virus with particular references to immunity and vaccination. World's Poultry Science Journal 59: 185-197.

26. Alexander DJ (2003) Newcastle disease and other avian Paramyxoviruses infections. In: Saif YM, Barnes HJ, Glisson JR, Fadly AM, McDougald LR, et al. (Edn) lowa State University Press Ames Pp 63-99. 
27. Orsi MA, Doretto L, Camillo SCA, Reischak D, Ribeiro SAM, et al. (2010) Prevalence of Newcastle disease virus in Broiler chickens (Gallus gallus) in Brazil. Brazilian Journal of Microbiology 41: 349-357.

28. Haque MH, Hossain MT, Islam MT, Zinnah MA, Khan MSR, et al. (2010) Isolation and Detection of Newcastle disease virus from field outbreaks in Broiler and Layer chickens by Reverse transcription-Polymerase chain reaction. Bangl J Vet Med 8: 87-92.

29. Iram N, Shah MS, Ismat F, Habib M, Iqbal M, et al. (2013) Heterologous expression, characterization and evaluation of the matrix protein from Newcastle disease virus as a target for antiviral therapies. Appl Microbiol Biotechno 98: 1691-701.

30. 30. Miller PJ, Afonso CL, Spackman E, Scott MA, Pedersen JC, et al. (2010) Evidence for a New Avian Paramyxovirus Serotype-10 Detected in Rockhopper Penguins from the Falkland Islands. J Virol 84: 11496-11504.

31. Waheed U, Siddique M, Arshad M, Ali M, Saeed A (2013) Preparation of Newcastle disease vaccine from VG/GA strain and its evaluation in commercial broiler chicks. Pakistan J Zool 45 339-344.

32. Terregino C, Aldous EW, Heidari A, Fuller CM, De Nardi R, et al. (2013). Antigenic and genetic analyses of isolate APMV/wigeon/ Italy/3920-1/2005 indicate that it represents a new avian paramyxovirus (APMV-12). Arch Virol, 158: 2233-2243.

33. Yamamoto E, Hiroshi I, Tomioka Y, Toshihiro I (2015) Characterization of novel avian paramyxovirus strain APMV/ Shimane67 isolated from migratory wild geese in Japan. J Vet Med Sci 77: 1079-1085.

34. Afonso $\mathrm{CL}$, Amarasinghe GK, Banyai $\mathrm{K}$, Bao $\mathrm{Y}$, Basler $\mathrm{CF}$, et al. (2016) Taxonomy of the order Mononegavirales. Arch Virology 161: 2351-2360.

35. Dimitrov KM, Ramey AM, Qiu X, Bahl J, Afonso CL (2016) Temporal, geographic, and host distribution of Avian Paramyxovirus 1 (Newcastle disease virus). Infect Genet Evol 39: 22-34.

36. Goraichuk I, Sharma P, Stegniy B, Muzyka D, Pantin-Jackwood MJ, et al. (2016) Complete genome sequence of an avian paramyxovirus representative of putative new serotype 13 Genome Announcement 4: 00729-00816.

37. Thampaisarn R, Bui VN, Trinh DQ, Nagai M, Mizutani T, et al. (2016) Characterization of avian paramyxovirus serotype 14, a novel serotype, isolated from a duck fecal sample in Japan. Virus Res 21: 46-57.

38. ICTV (2005) Virus Taxonomy: Classification and Nomenclature of Viruses: Eighth Report of the International Committee on the Taxonomy of Viruses. San Diego, Elsiever Academic Press.

39. Miller PJ, Estevez C, Yu Q, Suarez DL, King DJ (2009) Comparison of viral shedding following vaccination with inactivated and live Newcastle disease vaccines formulated with wild type and recombinant viruses. Avian Dis 53: 39-49.

40. Cattoli G, Susta L, Terregino C, Brown C (2011) Newcastle disease: $A$ review of field recognition and current methods of laboratory detection. J Vet Diagn Invest 23: 637-656

41. Madadgar O, Karimi V, Nazaktabar A, Kazemimanesh M, Ghafari MM, et al. (2013) A study of Newcastle disease virus obtained from exotic caged birds in Tehran between 2009 and 2010. Avian Pathol 42: 27-31.
42. Zhang S, Wang X, Zhao C, Liu D, Hu Y, et al. (2011) Phylogenetic and pathotypical analysis of two virulent Newcastle disease viruses isolated from domestic ducks in China. J PLOS ONE 6: 1-9.

43. Munir M, Abbas M, Khan TA, Zohari S, Berg M (2012a) Genomic and biological characterization of a velogenic Newcastle disease virus isolated from a healthy backyard poultry flock in 2010. Virology 9: 1-11.

44. Nanthakumar T, Kataria RS, Tiwari AK, Butchaiah G, Kataria JM (2000) Pathotyping of newcastle disease viruses by RT-PCR and restriction enzyme analysis. Vet Res Commun 24: 275-286.

45. Munir M, Zohari S, Abbas M, Berg M (2012b) Sequencing and analysis of the complete genome of Newcastle disease virus isolated from a commercial poultry farm in 2010. Arch Virol 157: 765-768.

46. Thomazelli LM, Araujo JD, Ferreira CS, Hurtado R, Oliveira DB, et al. (2012) Molecular Surveillance of the Newcastle Disease Virus in Domestic and Wild Birds on the North Eastern Coast and Amazon Biome of Brazil. Brazilian Journal of Poultry Science 14: 1-7.

47. Ameji ON, Sa'idu L, Abdu PA (2015) Newcastle Disease Antibodies in Apparently Healthy Wild Birds in Kogi State, Nigeria. Research Journal of Veterinary Sciences 8: 52-60.

48. Rezaeianzadeh G, Dadras H, Safar A, Ali M, Nazemshirazi MH (2011) Serological and molecular study of Newcastle disease virus circulating in village chickens of Fars province, Iran. J Vet Med Anim Health 3: 105-111.

49. Aziz AGT, Ahmed TA (2010) Serological Survey of Newcastle disease in Domestic chickens in Sulaimani Province. Journal of Zankay Sulaimani 13: 31-38.

50. Eze IA, Ike AC (2015) The Serological Status for Newcastle Disease in Local Chickens of Live bird Markets and households in Nsukka, Enugu State, Nigeria. Nigerian Journal of Microbiology 29: 3096-3104.

51. Mishra S, Katrina JM, Verma KC, Sah RL, Mishra JP (2001) Studies on the pathogenicity of Newcastle disease virus isolated in guinea fowl. Trop Anim Health Prod 35: 277-284.

52. Ohore OG, Ozegbe PC, Emikpe BO, Okojie VE (2002) Survey of antibodies to Newcastle disease virus in apparently healthy adult Nigerian indigenous chickens (Gallus domesticus) in Ibadan using ELISA. Af J Clinical and Experimental Microbiology 3: 38-40.

53. Mai HM, Ogunsola OD, Obasi OL (2004) Serological Survey of the Newcastle disease and infections bursal Disease in Local ducks and local guinea fowls In Jos, Plateau State, Nigeria. Revue Elev Med Vet Pays Trop 57: 41-44

54. Echeonwu GON, Iroegbu CU, Echeonwu BC, Ngene A, Olabode AO, ety al. (2007) Delivery of thermostable Newcastle disease (ND) vaccine to chickens with broken millet grains as the Vehicle. Afr J Biotechnol 6: 2694-2699.

55. Ibu OJ, Okoye JOA, Adulugba EP, Chah KF, Shoyinka SVO, et al. (2009) Prevalence of Newcastle disease viruses in wild and captive birds in Central Nigeria. Int J Poult Sci 8: 574-578.

56. Musa U, Abdu PA, Dafwang II, Umoh JU, Saidu L, et al. (2009) Seroprevalence, Seasonal occurrence and clinical manifestation of Newcastle disease in Rural Household Chickens in Plateau State, Nigeria. Int J Poult Sci 8: 200-204.

57. Nwankiti OO, Ejekwolu AJ, Ibrahim I, Ndako JA, Echeonwu GON (2010) Detection of Serum Antibody Levels against Newcastle Disease in Local Chickens in Bauchi Metropolis, Bauchi State, Nigeria. Afr J Cln Exper Microbiol 11: 95-101. 
58. Hassan SU, El-Yuguda AD, Gambo HI, Baba SS, Ambali AG, et al. (2016) Prevalence of Newcastle disease virus antibodies in sera and eggs of helmeted guinea fowls (Numida meleagris galeata pallas) in Borno and Yobe States, Nigeria. J Vet Sci 14: 49-52.

59. Ibitoye EB, Jimoh AA, Mungadi (2013) A Retrospective (2007 2011) Analysis of Newcastle Disease Diagnosed at avian clinic of Veterinary Teaching Hospital, Usmanu Danfodiyo University Sokoto, Nigeria. Current Research in Poultry Science 3: 12-17.

60. Alders R, Spradbrow PB (2001) Controlling of Newcastle disease in village chickens. Australian Centre for International Agriculture Research (ACIAR) 82: 1-112.

61. Sonaiya EB (2009) Fifteen years of family poultry research and development at Obafemi Awolowo University, Nigeria. In: Alders RG, Spradbrow PB, Young MP. Village chickens, poverty alleviation and the sustainable control of Newcastle disease. Tanzania. ACIAR Proceeding No. 131, Pp. 235

62. Alexander DJ, Aldous EW, Chad MF (2012) The long view: A selected review of 40 years of Newcastle disease research. Avian Pathol 41: 329-335.

63. Sa'idu L, Abdu PA (2008) Outbreak of Viscerotropic velogenic form of Newcastle disease in vaccinated six weeks old pullets. Sokoto J Vet Sci 7: 37-40.

64. Orsi MA, Doretto Jr.L, Reischak D, da Silva LH, Spilki DR, et al. (2009) Newcastle disease virus vaccine strains: Immunogenicity is not influenced by ICPI. Brazilian Journal of Poultry Science 11: 129-133.

65. Yan Z, Du Y, Zhao Q, Fan R, Guo W, et al. (2011) Mucosal immune responses against live Newcastle disease vaccine in immunosuppressed chickens. Pakistan Vet J 31: 280-286.

66. Van Boven M, Bouma A, Teun HFF, Elly K, Leo H et al. (2008) Herd immunity to Newcastle disease virus in Poultry by vaccination. Avian Pathol 37: 1-5.

67. Aldous EW, Alexander DJ (2001) Technical Review: Detection and differentiation of Newcastle disease virus (avian paramyxovirus type-1). Avian Pathol 30: 17-128.

68. Boynukara B, Gulhan T, Coven F, Kiziroglu I, Durmus A (2013) Determination of Newcastle disease virus among wild bird populations in Lake Van basin, Turkey. Turk J Vet Anim Sci 37: 1-9.

69. Cao Y, Gu M, Zhang X, Liu W, Liu X (2013) Complete Genome Sequences of Two Newcastle Disease Virus Strains of Genotype VIII. Journal of Genome Announc 1: 01.

70. Oladele BS, Abdu PA, Nok AJ, Esievo KAN, Useh NM (2002) Effect of some inhibitors on neurammidase of Newcastle disease virus Kudu 113 strain. Vet archiv 72: 185-194.

71. Abdu PA, Sa'idu L, Bawa EK, Umoh JU (2005a) Factors that Contribute to Newcastle Disease, Infectious Bursal Disease and Chicken Pox Outbreaks in Chickens. Proceedings 42nd NVMA Congress (Maiduguri 2005) Pp. 66-68.

72. Friend $M$ (2006) Evolving changes in diseases of waterbirds. In Waterbirds around the world. Boere GC, Galbraith CA, Stroud DA The Stationery Office, Edinburgh, UK, Pp. 412-417.

73. Sadiq MA, Nwanta JA, Okolocha EC, Tijjani AN (2011) Retrospective Study of Newcastle Disease (ND) Cases in Avian Species in Maiduguri, Borno State, North Eastern Nigeria. Int J Poult Sci 10: 76-81.

74. Mai HM, Qadeers MA, Bawa IA, Sanusi M, Tayong KN, et al. (2014) Seroprevalence of Newcastle disease in local chickens in Mezam division of North-west Cameroon. Microbiol Res Int 2: 9-12.
75. Abdu PA, Bawa EK, Umoh JU, Sa'idu L (2005b) Factors that Contribute to Newcastle Disease, Infectious Bursal Disease and Chicken Pox Outbreaks in Vaccinated Chickens. Proceedings 42nd NVMA Congress, Maiduguri Borno State, Pp 68-70.

76. Olabode HOK, Damina MS, Ahmed AS, Moses GD, Wungak YS (2012) Retrospective Study of Newcastle Disease in Commercial Poultry Farms in Ilorin, Kwara State Nigeria. Vom J Vet Sci 9: 66-70.

77. Njue SW, Machari JM, Gacheru SG, Mbugua HCW (2001) A survey of the disease status of village chickens in Kenya In: Proceedings 10th Conference for Tropical Veterinary Medicine (AIMVT). Copenhagen, Denmark 36.

78. Ngaji LW, Nyaga PN, Mbuthia PG, Bebora LC, Michieka JN, et al. (2010) Prevalence of Newcastle disease virus in village indigenous chickens in varied agro-ecological zones of Kenya. Livestock Research for Rural Development 18: 1-4.

79. Ekue FN, Pone KD, Mafeni MJ, Nfi AN, Njoya J (2002) Survey of the Traditional Poultry Production System in the Bamenda area, Cameroon. IAEA Vienna. http://www.iaea.or.at/programmes/ nafa/d3/public/2-surveyekue.pdf

80. Salum MR, Mtambuki A, Mulangila RCT (2002) Designing a vaccination regime to control Newcastle disease in village chickens in the Southern zone of Tanzania. Proceedings 17th Scientific Conference of the Tanzania Society for Animal Production 299-305.

81. Chaka H, Goutard F, Gil P, Abolnik C, Almeida R, et al. (2013) Serological and molecular investigation of Newcastle disease in household chicken flocks and associated markets in Eastern Shewa zone, Ethiopia. Trop Anim Health Prod 45: 705-714.

82. Getachew B, Moses NK, Balcha M, Dawo F (2014) Seroprevalence of Newcastle Disease Virus Antibodies in Village Chickens in Kersana-kondalaity District, Ethiopia. Global Veterinaria 12: 426-430.

83. Mohammed HA, Kumar S, Paldurai A, Samal SK (2011) Sequence analysis of fusion protein gene of Newcastle disease virus isolated from outbreaks in Egypt during 2006. Virol J 8: 01-04.

84. Olabode AO, Okwori AEJ, Echeonwu GON, Hodo SO, Adeyanju ON, et al. (2006) Antibody levels against NDV in rural chickens at slaughter point in Kubwa village, Abuja. Nigeria J Environ Sci 8: 449-454.

85. Yakubu A (2010) Indigenous chicken flocks of Nassarawa State, Nigeria: Their characteristics, husbandry and productivity. Tropical and Subtropical Agro-ecosystems 12: 69-76.

86. Nworie O, Ezeifeka GO, Ogbu O, Ogbu MA, Anyim C, et al. (2012) Sero-Prevalence of Newcastle Disease in Humans and Apparently Cross-Breed of Chickens in Nigeria. Cent. Euro J Exp Bio 1: 69-73.

87. Abraham-OJ, Sulaiman LK, Meseko CA, Ismail S, Ahmed SJ, et al (2014) Seroprevalence of newcastle disease virus in local chicken in Udu Local Government Area of Delta State, Nigeria. Int J Adv Agric Res 2: 121-125.

88. Abraham-Oyiguh J, Sulaiman LK, Meseko CA, Ismail S, Suleiman I, et al. (2014) Prevalence of Newcastle Disease Antibodies in Local Chicken in Federal Capital Territory, Abuja, Nigeria. International Scholarly Research Notices Vol. 2014.

89. Jibril AH, Umoh JU, Kabir J, Saidu L, Magaji AA, et al. (2014) Newcastle disease in local chickens of live bird markets and households in Zamfara State, Nigeria. International Scholarly Research Notices: Epidemiology Pp. 1-4. 
90. Sule AG, Abdu PA, Ajogi J, Amoh JU (2013) A Serological Survey for Newcastle Disease Virus Antibobies in Village Poultry in Yobe State, Nigeria. Nigerian Vet J 34: 775-780.

91. Wakawa AM, Abdu PA, Umoh JU, Sa'idu L, Miko RB (2009) Serological evidence of mixed infections with avian influenza and Newcastle disease in village chickens in Jigawa State, Nigeria. Vet Archv 79: 151-155.

92. Salihu AE, Chukwuedo AA, Echeonwu GON, Ibu JO, Chukwuekezie $J O$, et al. (2012) Seroprevalence of Newcastle disease virus infection in rural household birds in Lafia, Akwanga and Keffi Metropolis, Nasarawa State Nigeria. Int J Agric Sci 2: 109-112.

93. Hassan DI, Yusuf ND, Musa-Azara IS, Ari MM, Ogah DM, et al. (2013) Prevalence of Newcastle Disease in Village Chickens reared in Lafia, Nasarawa State, Nigeria. Egypt Poult Sci 33: 135-142.

94. Nwanta JA, Umoh JU, Abdu PA, Ajogi I, Alli-Balogun JK (2006) Management of losses and Newcastle disease in rural poultry in Kaduna State, Nigeria. Nigerian J Anim Prod 3: 274-285.

95. Anonymous (2007): National Population Commission 2007, online Nigeria, Gombe State. http://www.population.gov.ng/index.php/ gombe-state

96. Anonymous (2009): Online Nigeria, Gombe State. Wikipedia free encyclopedia. https://en.wikipedia.org/wiki/Gombe_State

97. Thrusfield M (2005) Veterinary epidemiology. London : Blackwell Science Ltd. Pp. 228-246.

98. Food and Agriculture Organization (FAO) (2012): Principle of hemagglutination test.

99. Baba SS, El-Yuguda AD, Baba MM (1998) Serological evidence of mixed infection with Newcastle disease and Egg drop syndrome 1976 viruses in Village chicken in Borno state, Nigeria. Tropical Veterinarian 16: 137-141.

100. Allan WH, Gough RE (1974) A Standard Haemagglutinationinhibition test for Newcastle disease: A comparison of macro-and micromethods. Vet Rec 95: 120-123.

101. Newcombe RG (1998) Two-Sided confidence intervals for the Single Proportion: Comparison of Seven Methods. Statistics in Medicine 17: 857-872.

102. Okwor EC, Eze DC (2013) Newcastle disease in layers: Preliminary studies on the stress associated with onset of lay and initiation of clinical disease. Afr J Microbiol Res 7: 960-965.

103. OIE (2004) Newcastle disease. Manual of Diagnostic Tests and Vaccines for Terrestrial Animals. Chapter 2.1. http://www.oie.int .

104. OIE (2012) Newcastle disease. Manual of Diagnostic Tests and Vaccines for Terrestrial Animals. Chapter 2.3. http://www.oie.int/ international-standard-setting/terrestrial-manual/access-online

105. Lawal JR, Jajere SM, Mustapha M, Bello AM, Wakil Y, et al. (2015) Prevalence of Newcastle Disease in Gombe, Northeastern Nigeria: A Ten-Year Retrospective Study (2004-2013). British Microbiology Research Journal 6: 367-375.

106. Bobbo AG, Baba SS, Yahaya MS, El-Yuguda AD (2013) Susceptibility of Three Phenotypes of Village Chickens to Newcastle Disease in Adamawa State. Alexandria Journal of Veterinary Sciences 39 : 133-140.
107. Ameji ON, Abdu PA, Saìdu L (2011) Seroprevalence of Avian influenza and Newcastle disease and Gumboro disease in chicken in Kogi State, Nigeria. Bulletin of Animal Health and Production in Afric 59: 411-418.

108. Chollom SC, Emerhirhi FT, Akwaowo EE, Ogbaji JU, Fyaktu EJ, et al. (2013) Implication of Newcastle disease virus in local chickens at Live Bird Markets in Jos. Nigeria Int J Cur Res 5: 2872-2874.

109. Okwor EC, Eze DC (2011) Epizootic Newcastle disease in loca chickens reared in south East Savannah zone of Nigeria. Int J Poult Sci 10: 212-215.

110. Ibu OJ, Aba-Adulugba A, Adeleke MA, Tijjani AY (2000) Activity of Newcastle disease and infectious bursal disease viruses in ducks and guinea fowls in Jos area, Nigeria. Sokoto J Vet Sci 2: 45-46.

111. Okeame AN, Folorunsho AD, Falayi BA (1988) An outbreak of Newcastle disease in guinea fowls (Numida meleagris) in Nigeria. Bulletin of Animal Health and Production in Africa 36: 176-17.

112. Haruna ES, Shamaki D, Echeonwu GO, Majiyagbe KA, Shuaibu Y, et al. (1993) A natural outbreak of Newcastle disease in guinea-fowl (Numida meleagris galeata) in Nigeria. Revue Sci Tech 12: 887-893.

113. Hassan SU, El-Yuguda AD, Gambo HI, Maidala HMB, Baba SS, et al. (2014) A natural outbreak of Newcastle disease among guinea fowls (Numida meleagris galeata pallas) in Maiduguri North Eastern Nigeria. Sahel J Vet Sci 13: 63-67.

114. Boakye OD, Emikpe BO, Folitse RD, Bonnah SG, Adusei K, et al. (2016) Serological Detection of Newcastle Disease Virus Antibodies in Local Chickens and Guinea Fowls in the Area of Kumasi, Ghana. Brazilian J Poult Sci 18: 87-92.

115. Sa'idu L, Tekdek LB, Abdu PA (2004) Prevalence of Newcastle disease antibodies in domestic and semi-domestic birds in Zaria, Nigeria. Vet Archv 74: 309-317.

116. Oladele SB, Kazeem HM, Raji MA (1996) Survey for antibodies to infectious bursal disease, Newcastle disease and fowl pox in ducks, pigeons and guinea fowls in Zaria. Nigeria Vet J 1: 85-87.

117. Miller PJ, Koch G (2013) Newcastle disease. In: Swayne DE, Glisson JR, McDougald LR, Nolan LK, Suarez DL; Diseases of poultry. WileyBlackwell, Hoboken.

118. Alexander DJ (2011) Newcastle disease in the European Union 2000 to 2009. Avian Pathol 40: 547-558.

119. Allan WH, Lancaster JE, Toth B (1978) ND vaccines their production and use. In: Animal Production and Health Series. Number 10. Italy, Food and Agricultural Organization publication. Pp. 1-163.

120. Wambura PN (2010) Detection of antibody to Newcastle disease virus in semi-domesticated free-range birds (Numida meleagris and Columber livia domestica) and the risk of transmission of Newcastle disease to village chickens. Vet Archv 80: 129-134.

121. Kapczynski DR, Afonso CL, Miller PJ (2013) Immune responses of poultry to Newcastle disease virus. Dev Comp Immunol 41: 447-453. 